\title{
Micropropagation of Chapada Diamantina ornamental bromeliad
}

\section{Andressa Priscila Piancó Santos Lima ${ }^{1 *}$ Alone Lima Brito ${ }^{2}$ (iD) José Raniere Ferreira de Santana ${ }^{2}$ (D)}

${ }^{1}$ Programa de Pós-graduação em Recursos Genéticos Vegetais, Universidade Estadual de Feira de Santana (UEFS), 44036-900, Feira de Santana, BA, Brasil. E-mail: andressapianco@gmail.com. ${ }^{*}$ Corresponding author.

${ }^{2}$ Departamento de Ciências Biológicas, Universidade Estadual de Feira de Santana (UEFS), Feira de Santana, BA, Brasil.

ABSTRACT: Sincoraea mucugensis (Wand. \& A.A. Conc.) LOUZADA \& WAND, an endangered bromeliad, is confined to the central region of the Chapada Diamantina, in the municipality of Mucuge, Brazil. From various researches, it is evident that for the propagation of this species, the in vitro technique is a feasible option. However, due to the low multiplication rates reported in various papers, this study aimed to establish a micropropagation protocol of direct organogenesis for S. mucugensis. First, the inoculation of the stem explants was done in MS $1 / 2$ culture medium which contained different levels of BAP $(0.00 ; 6.66 ; 8.88 ; 11.10 ; 13.20 \mu M)$ and NAA $(0.00 ; 2.60 ; 5.20 \mu M)$. These shoots were then subjected to a couple of distinct rooting periods (of 30-and 60-day duration) using activated charcoal; finally, these microplants were transferred to a greenhouse for acclimatization, and covered with transparent plastic cups, as a water loss prevention test method. All the data were submitted to the analysis of variance (ANOVA), and the means were subjected to regression analysis or compared using the Tukey test. The findings revealed that the $S$. mucugensis stem explants raised in the NAA-rich medium (6.42 to 7.43 shoots/explants) showed high multiplication rates; the shoot rooting was done for 30 days using activated charcoal with the medium. Acclimatization, which was performed by directly exposing the microplants to the ex vitro environment, showed $95 \%$ survival rate.

Key words: in vitro propagation, acclimatization, Sincoraea mucugensis, NAA.

Micropropagação de bromélia ornamental da Chapada Diamantina

RESUMO: Sincoraea mucugensis (Wand. \& A.A. Conc.) LOUZADA \& WAND é uma bromélia vulnerável de ocorrência restrita ao município de Mucugê, Chapada Diamantina. Estudos indicam que a cultura de tecidos é uma alternativa viável para a propagação in vitro desta espécie. Contudo, em função das baixas taxas de multiplicação obtidas em estudos anteriores, objetivou-se estabelecer um protocolo de micropropagação via organogênese direta para $S$. mucugensis. Explantes caulinares foram inoculados em meio de cultura MS $1 / 2$ contendo diferentes concentrações de BAP $(0,00 ; 6,66 ; 8,88 ; 11,10 ; 13,20 \mu M)$ e ANA $(0,00 ; 2,60 ; 5,20 \mu M)$. Os brotos obtidos foram submetidos a diferentes periodos de enraizamento (30 e 60 dias) com carvão ativado; posteriormente as microplantas foram aclimatizadas em casa de vegetação, testando-se o efeito da cobertura com copos plásticos transparentes como estratégias contra perda de água. Os dados foram submetidos à análise de variância (ANOVA) e as médias analisadas por regressão ou comparadas pelo Teste de Tukey. Os resultados demonstram que altas taxas de multiplicação de $S$. mucugensis são geradas a partir de explantes caulinares cultivados em meio contendo ANA (6,42 a 7,43 brotos/explantes); o enraizamento dos brotos é realizado por 30 dias em meio com carvão ativado e a aclimatização é feita com exposição direta das microplantas ao ambiente ex vitro com $95 \%$ de sobrevivência.

Palavras-chave: propagação in vitro, aclimatização, Sincoraea mucugensis, ANA.

\section{INTRODUCTION}

Sincoraea mucugensis (Wand. \& A.A. Conc.) LOUZADA \& WAND, is a vulnerable bromeliad, limited solely to the Chapada Diamantina of the Mucugê municipality, Brazil (LOUZADA \& WANDERLEY, 2010). The few number of plants acquired via natural propagation related to the predatory collection of the species are the reason for the development of research with the goal of propagating and conserving this genetic resource that has great potential for the ornamental plant market.
According to BELLINTANI et al. (2008) and LIMA et al. (2012), plant tissue culture is a good option and a feasible alternative to the propagation of S. mucugensis. However, compared to the other bromeliad genotypes, these authors recorded low in vitro shoot regeneration rates and; therefore, more intense studies are necessary to boost the proliferative rate of this species.

In multiplication via direct organogenesis, the plant tissues become the unipolar vegetative origination, where the vascular system is connected to the inceptive explant tissue (FARIA et al., 2007). This procedure is under the control of the signals 
produced by the cytokines and auxins, which are the plant regulators, and are also influenced by the parent plant genotype and its juvenile state. In fact, the culture medium, type and concentration of the auxin used greatly affect the rooting of the regenerated shoots (LEITZKE et al., 2009). Further, in the in vitro rooting of the bromeliads, the activated charcoal employed was found to exert a positive impact (BELLINTANI et al., 2007; LIMA et al., 2012).

To ensure that the microplants survive during the acclimatization, roots must definitely be present. This step is critical for the micropropagation to succeed, because the heterotrophic state (in vitro) is altered to the autotrophic one (ex vitro) accompanied by water loss, which can lower the plant vigor and even induce mortality (CATUNDA et al., 2008; ROCHA et al., 2008; LIMA-BRITO et al., 2016). To facilitate the gradual adaptation to the new environmental conditions, the microplants may go through a hardening period in vitro or be subjected to water loss reduction strategies, post transfer.

This study aimed to set up a micropropagation protocol of direct organogenesis for $S$. mucugensis.

\section{MATERIALS AND METHODS}

First, the S. mucugensis seeds were gathered from the Mucugê Municipal Park in Mucugê - Bahia, to act as the plant material. These seeds were then disinfested in a laminar flow chamber after soaking them for one minute in $70 \%$ alcohol and for 15 minutes in 3\% sodium hypochlorite; then they were sown in $250 \mathrm{~mL}$ flasks containing $50 \mathrm{~mL}$ of culture medium.

In all the experiments, the MS culture medium was employed (MURASHIGE \& SKOOG, $1962)$ with half saline concentrations (MS1/2). Then, 30 g.L $\mathrm{L}^{-1}$ sucrose gelled with 7 g.L $\mathrm{L}^{-1}$ agar (basic medium) was added as the supplement. With the medium $\mathrm{pH}$ being adjusted to 5.8 , sterilization was done for 15 minutes via autoclaving at $120^{\circ} \mathrm{C}$.

In the multiplication step, stem explants $0.5 \mathrm{~cm}$ in length were taken from 5-month-old plants, germinated in vitro and inoculated into tubes filled with $15 \mathrm{ml}$ of basic medium besides 6-benzylaminopurine - BAP in different concentrations $(0.00,6.66,8.88$, $11.10,13.20 \mu \mathrm{M})$ and naphthalene acetic acid - NAA $(0.00,2.60,5.20 \mu \mathrm{M})$. Adopting the completely randomized experimental design, which involved the $5 \times 3$ factorial arrangement (five BAP and three NAA concentrations), 15 treatments were done in total, with five replications for every treatment and three samples for every repetition; one explant was used in each sample. Evaluation of the variables was done after 60 days and the percentage of the explants with shoots (ES\%), and the number of shoots per explant (NSE) were noted.

Using the inoculation of the $2 \mathrm{~cm}$ long elongated shoots, rooting was performed in the free medium of the vegetable regulator. These shoots were inoculated into test tubes containing $15 \mathrm{ml}$ of the culture medium and 1 g.L. $\mathrm{L}^{-1}$ activated charcoal (BELLINTANI et al., 2007). Adopting the completely randomized experimental design, which included two rooting periods (of 30 and 60 days), each treatment involved 20 repetitions and two samples for every repetition, each having one explant. At the culmination of each period, the rooted shoot percentage (RS\%), numbers of roots (NR) and largest root length (LRL) were assessed.

The experiments, during the in vitro phases, were kept in a growth room and maintained at $25 \pm 3{ }^{\circ} \mathrm{C}$, for a 16 -hour photoperiod and under 60 $\mu \mathrm{mol} . \mathrm{m}^{-2} . \mathrm{s}^{-1}$ of active photosynthetic radiation.

The microplants rooted in vitro were placed in transparent disposable $200 \mathrm{ml}$ plastic cups and transplanted into the soil and vermiculite substrate (1:1) (BELLINTANI et al., 2007). At the time of transplantation, transparent disposable cups were used to cover half the number of the microplants $(50 \%)$ from each rooting step treatment, while the remaining half $(50 \%)$ were left under direct exposure to the greenhouse environment $(70 \%$ shade). The completely randomized statistical design was adopted, following a $2 \times 2$ factorial arrangement (two rooting times, and two exposure types during acclimatization), a total of four treatments: T1 30 rooting days and direct exposure; T2 - 30 days of rooting with cover; T3 - 60 days of rooting and direct exposure; T4 - 60 days of rooting with cover. Each treatment involved 20 repetitions. Once the microplants were transplanted to the greenhouse, the cups were left on a plastic slide tray. After 10 days, we removed the cups that had covered the samples. Every day the substrate was irrigated. Plant survival in percentage was assessed after 120 days.

All data were submitted to the analysis of variance (ANOVA) employing the SISVAR 5.1 statistical program (FERREIRA, 2003). The means were subjected to regression analysis or compared using the Tukey test at 5\% probability, respectively, for quantitative and qualitative data.

\section{RESULTS AND DISCUSSION}

From the analysis of variance, the BAP $x$ NAA interaction was evidently not significant for 
the shoot multiplication, showing considerable effect $(\mathrm{P} \leq 0.05)$ only for isolated variables. The auxin NAA revealed a crucial influence on the $\mathrm{ES} \%$, as well as the number of shoots per explant (NSE). The cytokine BAP; however, showed remarkable effect $(\mathrm{P} \leq 0.01)$ for the NSE alone.

The ES\% averages (97.33\% and $98.66 \%)$ for the two tested NAA concentrations showed similarity; although, with mostly values higher than the control (Table 1). This reiterates the vital role of the auxin in shoot induction in $S$. mucugensis. When plant regulators like the auxins are applied exogenously, the morphogenic responses of the plants in vitro are altered, with specific changes evident in the endogenous composition of the phytormonium.

The findings of the present study are better than those reported by BELLINTANI et al. (2008) and LIMA et al. (2012), for the same species, showing values of $39 \%$ and $56.67 \%$, on average, respectively, for $\mathrm{ES} \%$. Although, the same explant was employed in all the studies, the variations between the results are most likely due to the low levels of the plant regulators applied, in the studies cited, namely, 2.22 $\mu \mathrm{M}$ BAP in association with $0.65 \mu \mathrm{M}$ NAA.

For the NSE, behavior identical to those observed for ES\% were noted: the two NAA concentrations used also showed no difference in the values from each other (6.42 and 7.43), although they were above the average seen for the control (Table 1). This implies the favorable action of the added auxin towards increasing the shoot formation.

The positive effect of the NAA on the regeneration of shoots from the stem explants was demonstrated by SANTA-ROSA et al. (2013), as well as for the bromeliad Aechmea distichantha, in which the best results were seen in response to the highest concentration they used $(0.5 \mu \mathrm{M})$. MENDES

Table 1 - Percentage of the explants with shoots (ES\%) and number of shoots per explant (NSE) as a function of the NAA concentrations during the in vitro multiplication of Sincoraea mucugensis from shoot explants, post 60 days of cultivation.

\begin{tabular}{lccc}
\hline & & & \\
& & & \\
& & & \\
\hline & & & \\
Variables & 0.00 & 2.60 & 5.20 \\
ES\% & $77.33 \mathrm{~b}$ & $97.33 \mathrm{a}$ & $98.66 \mathrm{a}$ \\
$\mathrm{NSE}$ & $3.30 \mathrm{~b}$ & $6.42 \mathrm{a}$ & $7.43 \mathrm{a}$ \\
\hline
\end{tabular}

${ }^{*}$ Means followed by the same lower-case letters on the lines do not differ from each other by Tukey test at $5 \%$ probability. et al. (2007a) in their study on Billbergia distachia stem explants reported 5.3 shoots, on average, in response to the combined action of the $5 \mu \mathrm{M}$ BAP and $3 \mu \mathrm{M}$ NAA applied. This finding was different from that of the current research, in which no interaction was noted between the regulators in morphogenic response control.

When the influence exerted by the BAP on the NSE was examined, the regression analysis showed that the quadratic polynomial model was the most representative. When the regulator was added to the culture medium, it triggered a rise in the number of shoots, achieving the maximum level at $8.92 \mu \mathrm{M}$ concentration, with an approximate number of 6.89 shoots per explant. After this point, any increase in the BAP concentration only induced a reduction in the shoot formation (Figure 1).

This drop in the number of the $S$. mucugensis shoots seen, is likely due to the BAP toxicity when present in high concentrations (COLETTO et al., 2008). Interestingly, a similar effect was noted by the synthetic plant regulators and natural plant hormones, which can induce, modify or inhibit the plant growth and development-related metabolic processes (ALBUQUERQUE et al., 2008). According to SANTA-ROSA et al. (2013) the bromeliad Aechmea distichantha produced the greatest number of shoots, on average, from the shoot explants, when the lowest BAP concentration was used $(2.2 \mu \mathrm{M})$. The different responses by of species to the plant regulators may be due to the balance between the concentrations of the endogenous hormones the explant possesses and the concentrations of the exogenous regulators used.

In their studies on $S$. mucugensis, BELLINTANI et al. (2008) and LIMA et al. (2012) recorded the greatest for the number of shoots per explant, under the combined concentrations of BAP $(2.22 \mu \mathrm{M})$ and NAA $(0.65 \mu \mathrm{M})$. However, from the results listed here for both BAP and NAA, and irrespective of the concentrations used, the averages reported exceeded the highest average (1.37) reported by LIMA et al. (2012).

BELLINTANI et al. (2008) on studying $S$. mucugensis reported 7 to 12 shoots per explant, while the present study showed 6.42 and 7.43 as the highest averages in response to the addition of only NAA. However, in their research, these authors stated that the stem explants used were 6 months old, and that the response was improved when the BAP and NAA were used together and the experiment was evaluated after 6 months of cultivation. However, the regulators were used on 5-month-old explants, only an isolated 


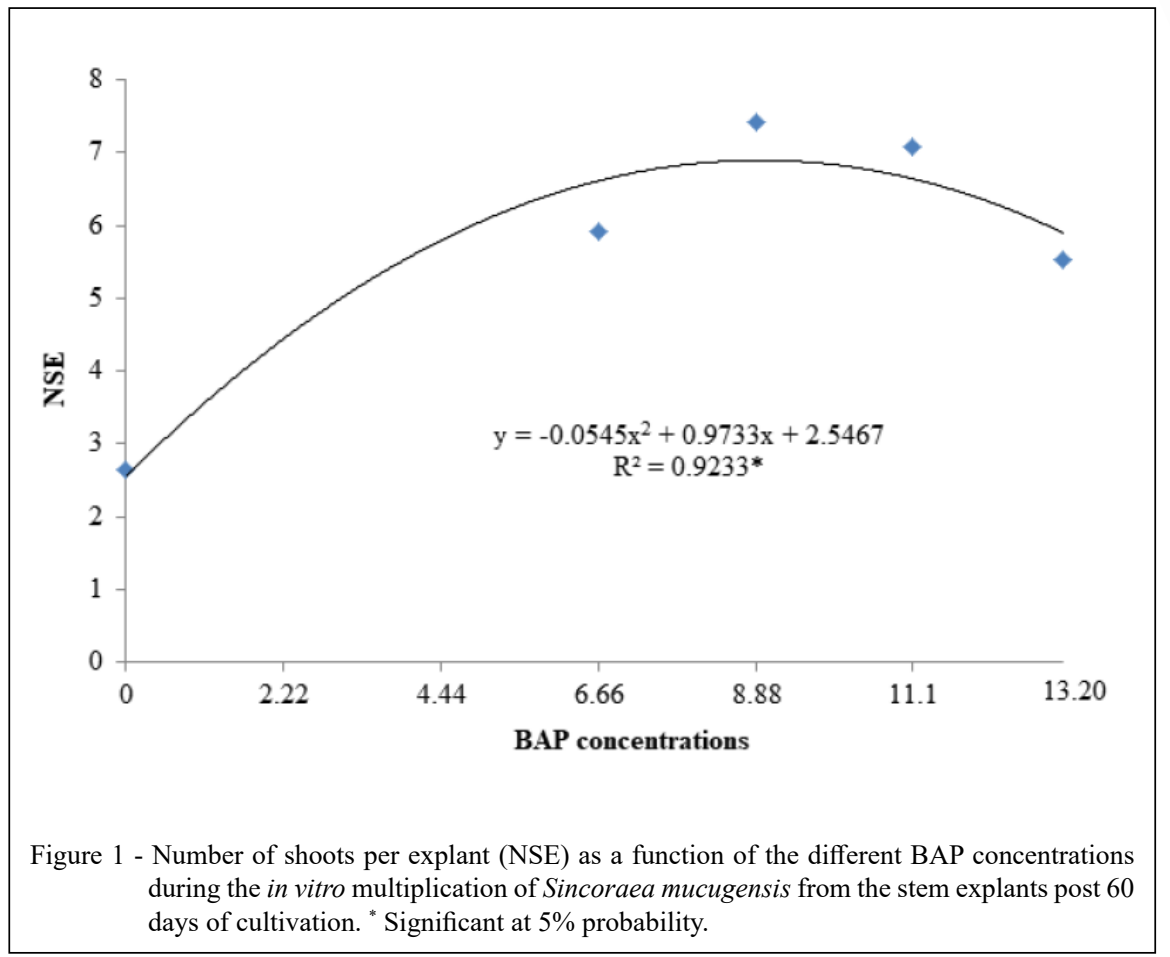

effect was observed, and the evaluation was done only on the 60-day rooting variety. Therefore, it is evident that shoots were produced within a shorter time span and under the influence of a single regulator, which may contribute towards the cost reduction in the micropropagated seedling yield.

During the rooting phase, the roots measured at the time of the two evaluation periods were thin, long and branched. The analysis of variance revealed a non-significant response to the $\mathrm{RS} \%$ variable $(\mathrm{P} \geq 0.05)$, which for the 30- and 60-day treatments showed $92.5 \%$ and $100 \%$ rooting (Table 2 ).

Highly significant responses to the treatment $(\mathrm{P} \leq 0.01)$ were seen for the variables number of roots (NR) and largest root length (LRL). In table 2, both NR and LRL indicate significantly higher outcomes in the 60-day treatment than in 30-day one.

In an earlier study, BELLINTANI et al. (2007) reported the in vitro rooting of $S$. mucugensis, in which activated charcoal 1 g. $\mathrm{L}^{-1}$ was added to the $\mathrm{MS}^{1} / 2$ culture medium in combination with sucrose of different concentrations; the authors however, did not include the root system analysis. In the research done by LIMA et al. (2012) using the same species, indole3-butyric acid (IBA) various concentrations was added, in combination or otherwise with activated charcoal of $1 \mathrm{gL}^{-1}$ added to the MS $1 / 2$ culture medium for the rooting, and recorded $4.90 \mathrm{~cm}$ for root length as the best average, only in the presence of charcoal. This corresponded to the findings of the current study, with $5.67 \mathrm{~cm}$ and $10.06 \mathrm{~cm}$, (on average) for the 30and 60-day periods, respectively.

In the studies of both BELLINTANI et al. (2007) and LIMA et al. (2012) on S. mucugensis,

Table 2 - Percentage of rooted shoots (RS\%), number of roots (NR) and largest root length (LRL) as a function of the 30- and 60-day rooting periods of Sincoraea mucugensis.

\begin{tabular}{lcc}
\hline & \multicolumn{3}{c}{-------Rooting Periods--------- } \\
\hline Variables & 30 days & 60 days \\
RS\% & $92.50 \mathrm{a}$ & $100 \mathrm{a}$ \\
$\mathrm{NR}$ & $2.95 \mathrm{~b}$ & $3.95 \mathrm{a}$ \\
$\mathrm{LRL}(\mathrm{cm})$ & $5.67 \mathrm{~b}$ & $10.06 \mathrm{a}$ \\
\hline
\end{tabular}

*Means followed by the same lower-case letters on the lines do not differ from each other by the Tukey test at $5 \%$ probability. 
the addition of activated charcoal to the culture medium was recommended for the 60-day period. This research also reported the positive effect exerted by the charcoal during in vitro rooting; in fact, even during the 30-day period there was a high rate of rooted explants which can reduce the maintenance time of the in vitro cultures, and consequently cut the production costs.

Several authors like MENDES et al. (2007b) working with Vriesea cacuminis and NAVES et al. (2005) with Alcantarea imperialis, highlighted the necessity for adding an auxin during the in vitro rooting of the Bromeliaceae species. These authors employed auxin NAA and reported 0.9 for root number and $3.9 \mathrm{~cm}$ for root length, on average, respectively. Their findings fall below the results of the current study, without the addition of any regulators, where the concentration of the endogenous auxin was adequate for the root initiation and production in the presence of activated charcoal, which stimulated the generated roots to elongate.

Coal has been utilized in the formation of adventitious roots as it physically provided a dark state in which roots normally show better development. Besides, coal modifies the culture medium composition chemically, as it has the ability to adsorb the residual and toxic constituents that inhibit rooting, such as phenols and quinones (ASSIS \& TEIXEIRA; 1998; GRATTAPAGLIA \& MACHADO, 1998; SOUZA \& PEREIRA, 2007).

The in vitro rooting step favors the success of micropropagation by providing higher survival rate of the microplants after they are transferred to the ex vitro environment. Therefore, once the rooting was evaluated, all the microplants were moved to the greenhouse.

No significant effect on acclimatization $(\mathrm{P} \leq 0.05)$ for $\mathrm{S} \%$, was evident for the interaction between rooting time $\mathrm{x}$ exposure type. Rooting time exhibited no significant isolated effect $(\mathrm{P} \leq 0.05)$. After 120 days, for the 30- and 60-day treatments, values of $95 \%$ and $97.5 \%$, respectively, were acquired.

The findings showed that despite the NR and LRL results in the rooting stage being better for the 60-day treatment, for plant survival in acclimatization, no difference was evident between the two testing periods; hence, the 30-day period is appropriate for rooting which is beneficial because it minimized the in vitro culture maintenance times. The findings of the current study; however, are contrary to the results reported from other works on bromeliads, in which rooting in vitro show longer times. In their research, NAVES et al. (2005) studying Alcantarea imperialis and SILVA et al. (2008) examining Dyckia maritime, followed a 60-day period for rooting the shoots. While MENDES et al. (2007b) maintained a 90-day in vitro culture period for rooting Vriesea cacuminis.

On considering the exposure type in acclimatization, no significant difference $(\mathrm{P} \leq 0.05)$ for $\mathrm{S} \%$ was noted between the covered and directly exposed plants, with results of $97.5 \%$ and $95 \%$, on average, respectively. This implies that the microplants have no necessity for acclimatization water loss control techniques.

These findings, however, do not concur with the reports from studies on other bromeliads, as evident from the works done by SILVEIRA et al. (2013) using Neoglaziovia variegata and SILVA et al. (2008) examining Dyckia maritime who, during acclimatization, employed in vitro microplant hardening techniques and water loss control methods.

BELLINTANI et al. (2008) demonstrated that after a 30-day period of rooting in vitro, the microplants needed to be subjected to another 30-day pre-acclimatization process, using cotton to keep the tubes closed. Besides, the authors indicate that the S. mucugensis microplants, during acclimatization, were maintained for 40 days, under the cover of pet bottles, they achieved $95.4 \%$ survival rate, post 100 days of transplantation. In the present research, the microplants did not experience an earlier hardening period, and demonstrated high in vitro survival rates.

The results, thus acquired through this study, clearly indicated that no strategies were required to harden and minimize the water loss, suggesting that direct transfer of the microplants is possible, from the 30-day rooting in vitro to the environment ex vitro without any loss of the microplants transplanted.

\section{CONCLUSION}

This study confirmed that for the production of Sincoraea mucugensis seedlings through direct organogenesis, micropropagation is a feasible option. Using auxin NAA, multiplication is accomplished from the stem explant. Microplants, after a 30day rooting duration using medium with activated charcoal, showing a high survival percentage, post acclimatization.

\section{ACKNOWLEDGEMENTS}

This research was financed in part by the Coordenação de Aperfeiçoamento de Pessoal de Nível Superior (CAPES), Brasil - Finance code 001. We also thank the Conselho Nacional de Desenvolvimento Científico e Tecnológico (CNPq) for the financial support. 


\section{DECLARATION OF CONFLICT OF INTERESTS}

The authors declare no conflict of interest. The founding sponsors had no role in the design of the study; in the collection, analyses, or interpretation of data; in the writing of the manuscript, and in the decision to publish the results.

\section{AUTHORS' CONTRIBUTIONS}

All authors contributed equally for the conception and writing of the manuscript. All authors critically revised the manuscript and approved of the final version.

\section{REFERENCES}

ALBUQUERQUE, T. C. S. et al. Plant growth regulators on macronutrients in Itália grapes. Bragantia [online]. v.67, n.3, p.553-561, 2008. Available from: <http://www.scielo.br scielo.php?script $=$ sci_arttext\&pid $=$ S00068705200800030000 1\&lng=pt\&nrm=iso $>$. Accessed: Feb. 21, 2016. doi:10.1590/ S000687052008000300001.

ASSIS; T. F.; TEIXEIRA, S. L. Enraizamento de plantas lenhosas. In: TORRES, A.C.; CALDAS, L. S.; BUSO, J. A. Cultura de tecidos e transformação genética de plantas. Brasília: Embrapa/ SPI, v.1, p.183-260, 1998

BELLINTANI, M. C. et al. Estabelecimento in vitro de Orthophytum mucugense e Neoregelia mucugensis, bromélias endêmicas da Chapada Diamantina, Bahia - Brasil. Revista Brasileira de Biociências, v.5, supl.2, p.1101-1103, 2007. Available from: <http://www.ufrgs.br/ seerbio/ojs/index.php/rbb/ article/view/872>. Accessed: Nov. 27, 2015.

BELLINTANI, M.C. et al. Resposta regenerativa in vitro de explantes caulinares de bromélias endêmicas da Chapada Diamantina- Bahia. Magistra [impresso], v.20, n.4, p.328-337, 2008.

CATUNDA, P. H. A. et al. Brassinosteroid and substrates in acclimatization of 'Imperial' pineapple. Acta Scientiarum Agronomy, v.30, n.3, p.345-352, 2008. Available from: $<$ http://www.scielo.br/scielo.php?script=sci_arttext\&pid $=$ S1807-86212008000300008 $>$. Accessed: Nov. 30, 2015. doi: 10.4025/actasciagron.v30i3.3512.

COLETTO, L. S. et al. Micropropagation of stock for grafting of grapevine paulsen 1103 "in vitro", with different citocinina concentrations. Revista da FZVA, v.15, n.1, p.102-108, 2008. Available from: $<$ http://revistaseletronicas.pucrs.br/ojs/index.php/ fzva/article/view/3706>. Accessed: Mar. 30, 2016.

FARIA, G. A. et al. Culture medium and type of explant in the in vitro establishment of passion fruit species. Bragantia, v.66, n.4, p.535-543, 2007. Available from: <http://www.scielo.br/ scielo.php?script=sci_arttext\&pid=S0006-87052007000400002>. Accessed:Nov.30,2015. doi:10.1590/S0006-87052007000400002.

FERREIRA, D.F. SISVAR Sistema de análises estatísticas. Lavras: UFLA, v.3, n.4. 2003.

LEITZKE, L. N. et al. Culture environment, IBA concentration and cultivation time on in vitro rooting of blackberry and raspberry. Revista Brasileira de Fruticultura, v.31, n.2, p.582-587, 2009. Available from: <http://www.scielo.br/scielo.php?script=sci artt ext\&pid=S0100-29452009000200037>. Accessed: Jan. 22, 2016. doi: $10.1590 / \mathrm{S} 0100-29452009000200037$.
LIMA, C. O. de C. et al. Direct organogenesis of Orthophytum mucugense. Ciência Rural, v.42, n.2, p.249-254, 2012. Available from: $<$ http://www.scielo.br/scielo.php?script $=$ sci arttext\&pid $=\mathrm{S}$ $010384782012000200011 \& \operatorname{lng}=\mathrm{pt} \& \operatorname{tlng}=\mathrm{pt}>$. Accessed: Dec. 05, 2015. doi:10. 1590/S0103-84782012000200011.

LIMA-BRITO, A. et al. In vitro hardening in different environment and acclimatization of microplants of Comanthera mucugensis Giul. subsp. mucugensis. Revista Ciência Agronômica, v.47, n.1, p.152-161, 2016. Available from: <http://www.scielo.br/ scielo.php? script $=$ sci arttext\&pid $=\mathrm{S} 1806-66902016000100152>$. Accessed: Jan. 22, 2016 doi: 10.5935/1806-6690.20160018.

LOUZADA, R. B.; WANDERLEY, M. das G. L. Revision of Orthophytum (Bromeliaceae): the species with sessile inflorescences. Phytotaxa, v.13, p.1-26, 2010. Available from: $<$ https://biotaxa.org/Phytotaxa/article/view/phytotaxa.13.1.1. $>$. Accessed: Jan. 22, 2016. doi:10.11646/phytotaxa.13.1.1.

MENDES, G. C. et al. Multiplicação in vitro de explantes de Billbergiadistachia (Vellozo) MEZ (Bromeliaceae). Revista Brasileira de Biociências, v.5, n.S2, p.972-974, 2007a. Available from: $<$ http://www. ufrgs.br/seerbio/ojs/index.php/rbb/issue/view/23>. Accessed:Apr. 12, 2016.

MENDES, G. C. et al. Enraizamento in vitro de Vriesea cacuminis LB Smith (Bomeliaceae) do Parque Estadual do Ibitipoca, Minas Gerais, Brasil. Revista Brasileira de Biociências, v.5, n.S2, p.969971, 2007b. Available from: <http://www.ufrgs.br/seerbio/ojs/ index.php/rbb/article/viewFile/794/676>. Accessed: Apr. 12, 2016.

MURASHIGE, T.; SKOOG, F. A revised medium for rapid grow than dbioassays with to bacco tissue culture. Physiology Plantarum, v.15, p.473-497, 1962

NAVES, V. C. et al. Rooting and acclimatization of in vitro regenerated shoots of imperial bromeliad. Ornamental Horticulture, v.11, n.1, 2005. Available from: <https://ornamental horticulture.emnuvens.com.br/rbho/article/view/25>. Accessed: May, 23, 2016. doi: 10.14295/rbho.v11i1.25.

ROCHA, M. A. C. da et al. In vitro rooting and acclimatation of genotypes of jenipapeiro (Genipa Americana L.). Revista Brasileira de Fruticultura, v.30, n.3, p.769-774, 2008. Available from: <http://www.scielo.br/scielo.php?script $=$ sci arttext\&pid $=\mathrm{S} 0100-294520080 \quad 00300035 \& \operatorname{lng}=\mathrm{pt} \& \mathrm{t} \operatorname{lng}=\mathrm{pt}>$. Accessed:Dec. 12,2015.doi: 10.1590/S0100-29452008000300035.

SANTA-ROSA, Sandra et al. Micropropagation of the ornamental vulnerable bromeliads Aechmea blanchetiana and Aechmea distichantha. Horticultura Brasileira, v.31, n.1, p.112-118, 2013. Available from: $<$ http://www.scielo.br/scielo.php?script=sci _arttext\&pid= S01 02-05362013000100018\&lng=en\&tlng=en $>$. Accessed: Mar. 10, 2017. doi:10.1590/S0102 05362013000100018.

SILVA, A. L. L. da et al. Micropropagation of Dyckia maritima Baker - Bromeliaceae. Iheringia Série Botânica, v.63, n.1, p.135-138, 2008. Available from: <https://isb.em nuvens.com.br/ iheringia/article/view/162>. Accessed: Oct. 19, 2016.

SILVEIRA, D. G. et al. Morpho-physiological aspects of in vitro preacclimatization and acclimatization of the caroá plant. Revista Ciência Agronômica, v.44, n.3, p.544, 2013. Available from: <http://www. scielo.br/scielo.php?script $=$ sci_arttext\&pid=S1806-6690201300 0300017\&lng=pt\&nrm=iso\&tlng=en $>$. Accessed: Jun. 03, 2017. doi:10.1590/S1806-66902 013000300017.

SOUZA, A. V.; PEREIRA, A. In vitro cultivated plant's rooting. Revista Brasileira de Plantas Medicinais, v.9, n.4, p.103-116, 2007. Available from: <https://repositorio. unesp.br/bitstream/ handle $/ 11449 / 69962 / 2-$ s2.0-38549176817.pdf? sequence $=1>$. Accessed: Jun. 03, 2017>. 